\title{
Distribution and zonation of Goatfishes (Family: Mullidae) inhabiting the Northern Red Sea, South Sinai, Egypt.
}

\author{
Hanaa M. Sarhan'; Magdy A. Alwany'; Wafaa Sallam and Redouan Bshary ${ }^{\mathbf{1}}$. \\ 1- Department of Marine Science, Faculty of Science, Suez Canal University, \\ Ismailia, Egypt. \\ 2- Department of Behavioural Ecology, Institute of Biology, University of Neuchâtel, \\ Switzerland.
}

\section{ABSTRACT}

Goatfish species are among the most common species of the Red Sea reef communities; however, there are only few attempts to describe the distribution of them in the Red Sea. The main aim of the study is to shed light on some ecological features of the Goatfish inhabiting the Red Sea reef. Observations were conducted along the eastern coast of Sinai Peninsula, South Sinai, Red Sea, Egypt. Visual census transects were established with timed swims along the study sites which were divided into three sections: the northern sites, the middle sites, and the southern sites. Six species of goatfishes were recorded (Parupeneus cyclostomus, $P$. macronima, $P$. indicus, P. forsskali, Mulloidichthys Vanicolensis, M. flavolineatus). P. macronima had the highest abundance, while $M$. flavolineatus had the lowest at all sites. In general, the number of species is not influenced by the sites $(p=0.774)$, while the number of individuals varied significantly among sites $(p=0.065)$. The zones have significant effect on the abundance of species, as the number of individuals was higher in the reef slope than in the reef flat $(P=0.060)$, and the number of species was also higher on the reef slope than the reef flat $(p=0.071)$. Sizes of goatfish individuals were bigger in the reef slope than the reef flat, but not in a significant way $(p=0.182)$.

Keywords: Goatfishes, distribution, zonation, abundance, size degradation, Red Sea.

\section{INTRODUCTION}

Goatfishes (Mullidae) constitute a family of marine fish species that are commercially important. They can be easily recognized by the presence of a pair of long movable hyoid barbels on the chin (Randall 1983; Nelson 2006).Goatfishes are tropical marine perciforms with six genera and about 70 species (Randall, 2004; Nelson, 2006; Uiblein \& Heemstra 2010). However, there are only 13 species had recorded in the Red Sea (Dor \& Ben-Tuvia, 1984; Randall, 1983 and 2004). Additionally, members of the genus Parupeneus from the Red Sea species were previously recorded by Lessepsian fishes in different parts of the Mediterranean (Çinar et al., 2006; Azzurro et al., 2011; Bariche et al., 2013). There are only few attempts to describe the distribution of the Goatfishes species in the Red sea (Golani, 1999; Al-Rousan et al., 2005).

Goatfishes show a very common presence and a considerable variation in social organization, with the adults found either in small to large schools, as solitary wanderers, or in dominance hierarchies (Munro, 1976; Gosline, 1984; El-Drawany, 2013). Many of the goatfishes are zoobenthivores and forage mainly over soft sediments (sand and mud) around reefs, oriented mostly by their tactile and chemosensory barbells (Gosline, 1984; McCormick, 1995; Lukoschek \& 
McCormick, 2001; Kim, 2002). The goatfishes are common and abundant in tropical and subtropical shallow reefs, and two or more species of them may occur on the same location (Gosline, 1984; Golani, 1994; McCormick, 1995).

Foraging strategies vary; some species search mainly for epibenthic prey, whereas others penetrate deeper into the substrate (McCormick, 1995; Platell et al., 1998; Platell \& Potter 2001). As a result, different species feed on different invertebrate prey communities. The main food categories in the diet of mullids are crustaceans, polychaetes and molluscs, but they also feed on small fishes, fish eggs and echinoderms (Platell et al., 1998; Platell \& Potter, 2001; Stergiou \& Karpouzi, 2001). Such differences in hunting habitats are believed to minimize the overlap of food resources between co-occurring species (Munro, 1976; Labropoulou \& Eleftheriou, 1997; Karajewski, et al., 2006). During their foraging, the goatfishes disturb the substratum and, thus, change the bottom topography and the distribution of invertebrates associated with soft sediments (McCormick, 1995).

Most coral reefs show a clear zonation and, within a reef, numbers and types of organisms may vary in the different zones (Bell \& Galzin, 1984). Fishes are also influenced by this reef zonation, which is reflected in great spatial heterogeneity in terms of substrate composition and structural complexity (Done, 1982; Glynn et al., 1996; Rajasuriya et al., 1998). Accordingly, certain fish species or assemblages are characteristic for certain zones (Bell \& Galzin, 1984; Harmelin-Vivien, 1989; Alwany, 1997; McClanahan \& Arthur, 2001; Garpe \& Öhman, 2003). They may be selective or non-selective, obligate, facultative or opportunistic in relation to their habitat (Bergman et al., 2000).

The main aim of the study is to examine the distribution pattern and diversity of goatfishes on shallow (1.0 to $8 \mathrm{~m}$ depth) Egyptian Red Sea Reefs and to shed light on some ecological features of the Goatfishes (family: Mullidea). The primary objective of this study was to describe spatial patterns of distribution, abundance and zonation of Mullid fishes along $270 \mathrm{~km}$ from north Gulf of Aqaba to the end of Ras Mohamed in south, Red Sea. This information is essential due to limited studies on the distribution patterns of fish within Red sea reef systems, especially at the Northern parts of the Red Sea.

\section{MATERIAL AND METHODS}

\section{Study area:}

All observations were conducted along the eastern coast of Sinai Peninsula, Red Sea, Egypt in February 2014. Three different topographical reefs were studied along the Gulf of Aqaba, from north Gulf to the end of Ras Mohamed in south of the Red Sea, spanning a distance of $270 \mathrm{~km}$ (Fig. 1). The study sites, which are shown in Fig. (1), were divided into three sections: Northern sites; (1) Ras Mamlah and (2) Ras Abu Galoum, Middle sites; (3) Rix reef and (4) Mashraba reef, and Southern sites; (5) Ras Nasrani and (6) Ras Ghezlani. 


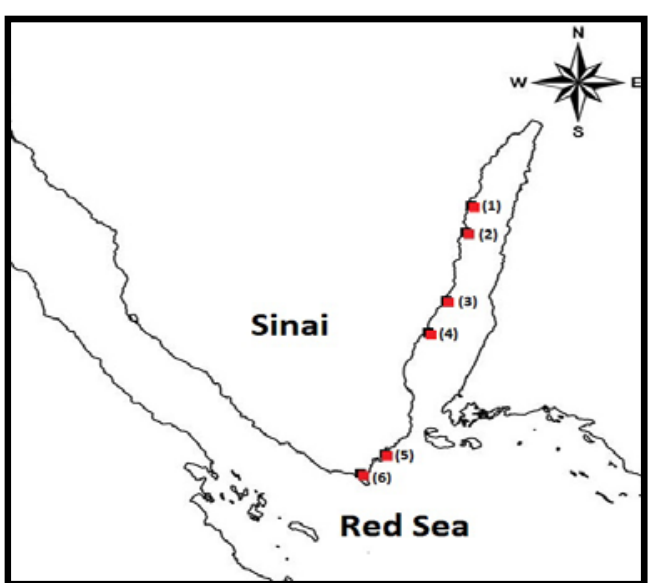

Fig. 1: Map of South Sinai and Gulf of Aqaba, showing the locations of the different sites of the study area.

\section{Data collection and studied species:}

All observations were done by snorkeling. The data were written on plates for later transfer to a computer. A $100 \mathrm{~m}$ visual census transects were established with timed swims. A timed swim is imperative to estimate the distance swim (using a GPS) and record the time accurately (using stopwatch). During moderate sea condition we estimated 6 min swim against the current, and 4 min swim with the current, with 2 min intervals. At each site; three continued replicates laid parallel to the shore were conducted in three different zones; reef flat (RF) to $1 \mathrm{~m}$, reef edge (RE) to $4 \mathrm{~m}$ depth, and reef slop (RS) to $8 \mathrm{~m}$ depth. Goatfishes were recognized through distinguished body colorations and patterns. Individuals of Goatfish were observed, identified and recorded along the transects and the approximation of body sizes was estimated using a fixed scale. On the reef flat, fishes were observed using snorkeling, on the reef slope using SCUBA during day-time from 11:00 to 14:00 $\mathrm{h}$.

\section{Statistics:}

The data were analyzed statistically using the software packages PRIMER (V 5.0) and SPSS (V 19.0), that was used to determine the difference between sites, zones and species. Species diversity was expressed by considering the number of species (D), but homogeneity were determined using the Shannon-Wiener diversity index $\left(\mathrm{H}^{\prime}\right)$ and the evenness index $\left(\mathrm{J}^{\prime}\right)$, (Pielou, 1966). These parameters were calculated for each site by pooling data from the sample replicates. When necessary, abundance data were square root transformed to produce normality and homogeneity of variance.

\section{RESULTS}

\section{Distribution of goatfishes:}

The mean abundance of the recorded species in the different reef zones selected sites is shown in Table (1) and Fig. (2). Six species of goatfishes were recorded (Parupeneus cyclostomus, P. macronima, P. indicus, P. forsskali, Mulloidichthys Vanicolensis, M. flavolineatus). In General, the number of species is not influenced by the sites $(p=0.774)$, while the number of individuals varied significantly among sites $(p=0.065)$. In general, Parupeneus macronima had the highest abundance, while Mulloidichthys flavolineatus had the lowest one at all sites. At the reef flat, $P$. macronima had highest abundance of $8.3 \mathrm{fish} / 500 \mathrm{~m}^{3}$ at site 5 (Table 1), while at reef edge, $P$. cyclostomus was the most abundant species $\left(7.7 \mathrm{fish} / 500 \mathrm{~m}^{3}\right.$ at most 
southern sites). P. indicus was the highest abundant (12.0 fish $/ 500 \mathrm{~m}^{3}$ at site 5) (Table 1). Mashraba reef (Site 4, at the middle section of Dahab city) had the lowest number of species (three species) on reef flat, while it had four species on the reef edge and slope. Variations in the goatfish species along the six sites were not changed.

Table 1: The mean abundance $( \pm \mathrm{SD})$ of Mullidae fishes species on the reef flat, reef edge and reef slope at different six sites along Gulf of Aqaba.

\begin{tabular}{|c|c|c|c|c|c|c|}
\hline \multicolumn{7}{|c|}{ Reef Flat } \\
\hline Species & Site 1 & Site 2 & Site 3 & Site 4 & Site 5 & Site 6 \\
\hline Parupeneus cyclostomus & 0 & $1.0 \pm 0$ & 0 & 0 & $2.0 \pm 1.0$ & $2.7 \pm 1.0$ \\
\hline P. macronima & $4.3 \pm 1.3$ & $2.3 \pm 0.9$ & $6.7 \pm 3.1$ & $6.7 \pm 2.1$ & $8.3 \pm 3.2$ & $6.7 \pm 1.3$ \\
\hline P. indicus & 0 & 0 & 0 & 0 & 0 & 0 \\
\hline P. forsskali & $4.0 \pm 1.9$ & $3.3 \pm 0.8$ & $5.7 \pm 1.8$ & $4.3 \pm 2.2$ & $3.0 \pm 1.2$ & $5.7 \pm 2.9$ \\
\hline Mulloidichthys vanicolensis & 0 & 0 & 0 & 0 & 0 & 0 \\
\hline M. flavolineatus & 0 & $1.0 \pm 0$ & $1.3 \pm 0.1$ & $1.0 \pm 0$ & $2.7 \pm 0.3$ & $1.3 \pm 0$ \\
\hline \multicolumn{7}{|c|}{ Reef Edge } \\
\hline Species & Site 1 & Site 2 & Site 3 & Site 4 & Site 5 & Site 6 \\
\hline P. cyclostomus & $5.7 \pm 3.1$ & $6.0 \pm 2.1$ & $7.7 \pm 2.6$ & $7.7 \pm 2.9$ & $7.7 \pm 1.0$ & $7.7 \pm 1.9$ \\
\hline P. macronima & $4.0 \pm 2.0$ & $5.7 \pm 2.0$ & $5.0 \pm 1.8$ & $5.2 \pm 2.0$ & $5.0 \pm 0.9$ & $5.0 \pm 0.7$ \\
\hline P. indicus & $2.7 \pm 1.3$ & $8.3 \pm 4.1$ & $6.0 \pm 0.2$ & $6.3 \pm 3.3$ & $5.3 \pm 3.3$ & $6.6 \pm 2.5$ \\
\hline P. forsskali & 0 & 0 & 0 & 0 & 0 & 0 \\
\hline Mulloidichthys vanicolensis & 0 & $1.7 \pm 0.2$ & $1.7 \pm 0.1$ & $1.7 \pm 0.3$ & $1.7 \pm 0.1$ & $1.7 \pm 0.1$ \\
\hline M. flavolineatus & 0 & 0 & 0 & 0 & 0 & 0 \\
\hline \multicolumn{7}{|c|}{ Reef Slope } \\
\hline Species & Site 1 & Site 2 & Site 3 & Site 4 & Site 5 & Site 6 \\
\hline P. cyclostomus & $3.7 \pm 1.2$ & $5.0 \pm 2.1$ & $4.7 \pm 1.8$ & $4.3 \pm 1.9$ & $4.3 \pm 1.0$ & $4.7 \pm 2.1$ \\
\hline P. macronima & $1.7 \pm 0.2$ & $5.7 \pm 1.7$ & $5.7 \pm 2.1$ & $5.7 \pm 1.7$ & $5.7 \pm 1.7$ & $5.7 \pm 1.2$ \\
\hline$P$. indicus & $4.0 \pm 1.9$ & $9.3 \pm 3.2$ & $9.3 \pm 4.1$ & $9.0 \pm 3.1$ & $12.0 \pm 0.5$ & $9.3 \pm 0.7$ \\
\hline P. forsskali & 0 & 0 & 0 & 0 & 0 & 0 \\
\hline Mulloidichthys vanicolensis & 0 & $3.0 \pm 1.8$ & $4.3 \pm 2.1$ & $4.3 \pm 1.9$ & $10.3 \pm 3.2$ & $4.3 \pm 1.0$ \\
\hline M. flavolineatus & 0 & 0 & 0 & 0 & 0 & 0 \\
\hline
\end{tabular}

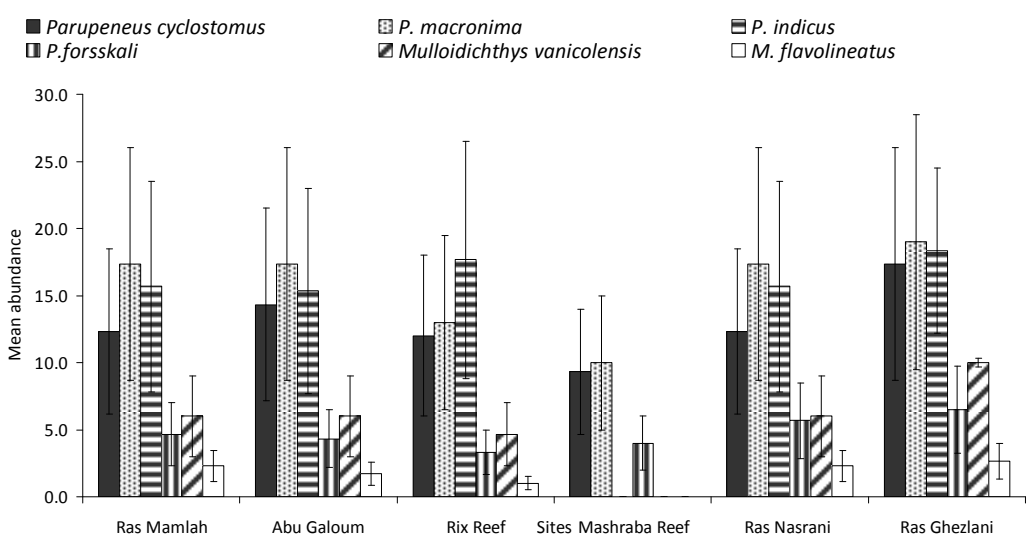

Fig. 2: The mean abundance ( $\pm \mathrm{SD}$ ) of the goatfish species in the selected sites along the Gulf of Aqaba coast.

\section{Abundance of goatfishes on the different reef zones:}

The average number of species and individuals on the mentioned three reef zones at the six sites is given in Figs. ( $3 \mathrm{a}$ and $\mathrm{b}$ respectively). The zones have a 
significant effect on the abundance of species, as the number of species was higher on the reef slope than the reef flat $(p=0.060)$. The density of goatfishes varied significantly among zones $(p=0.071)$, as the number of individuals was also higher on the reef slope than the reef flat. Ras Nasrani (site 5) had the highest abundance (209 fish) in all three zones (in south at Sharm El-Sheikh), while Mashraba reef (site 4) had the lowest abundance (90 fish) in all three zones (in middle of Gulf at Dahab).
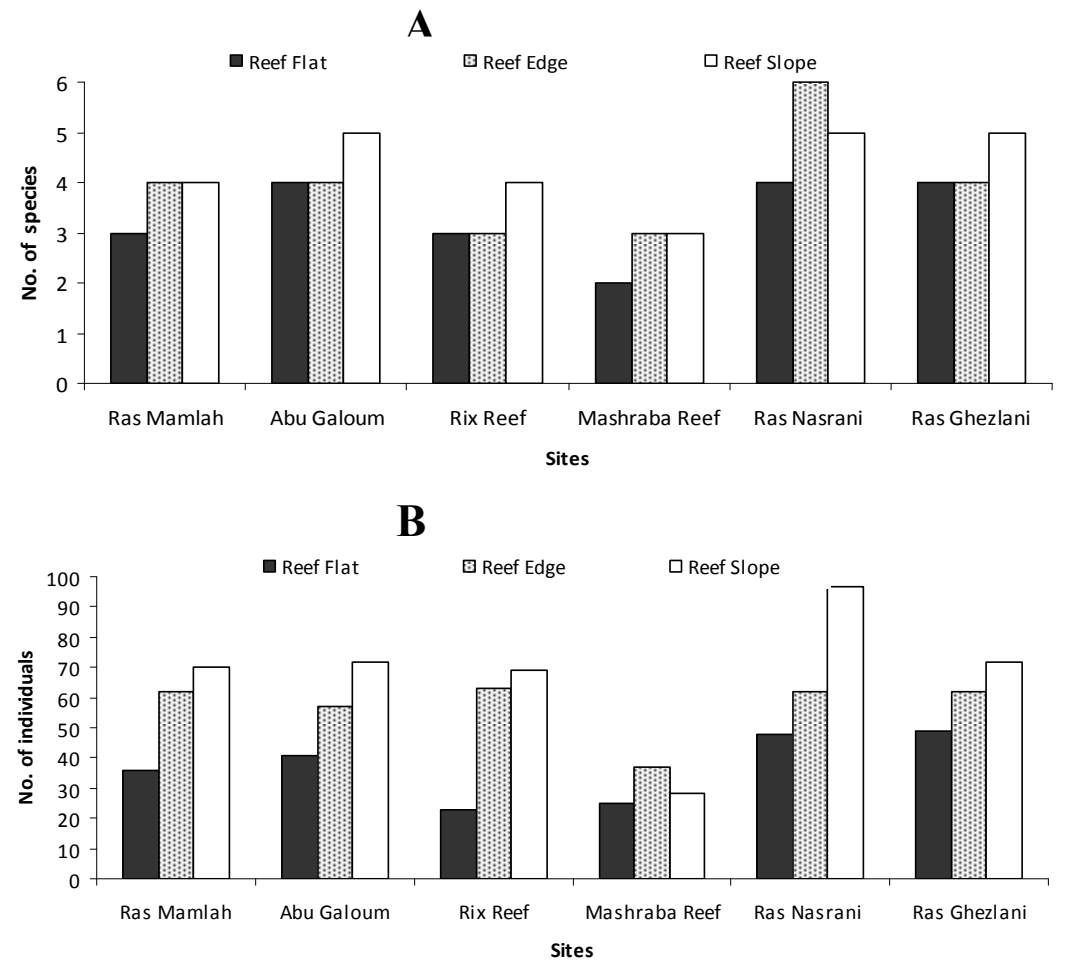

Figs. 3: A and B: number of species and individuals of goatfishes at the different reef zones.

\section{Fish Community parameters of diversity:}

Figs $4 \mathrm{a}, \mathrm{b}$, and c illustrate the average species richness ranged from $(0.39)$ at the reef edge of Ras Mamlah to (0.83) at reef flat of Rix Reef. The highest evenness diversity index $\left(\mathrm{J}^{\prime}\right)$ was recorded at the reef edge of Ras Mamlah (0.92), while the reef flat of Rix Reef showed the lowest value (0.33), while the average Shannon Wiener diversity $\left(\mathrm{H}^{\prime}\right)$ varied between 2.8 at the reef flat of Rix Reef and (0.37) at the reef edge of Abu Galoum.

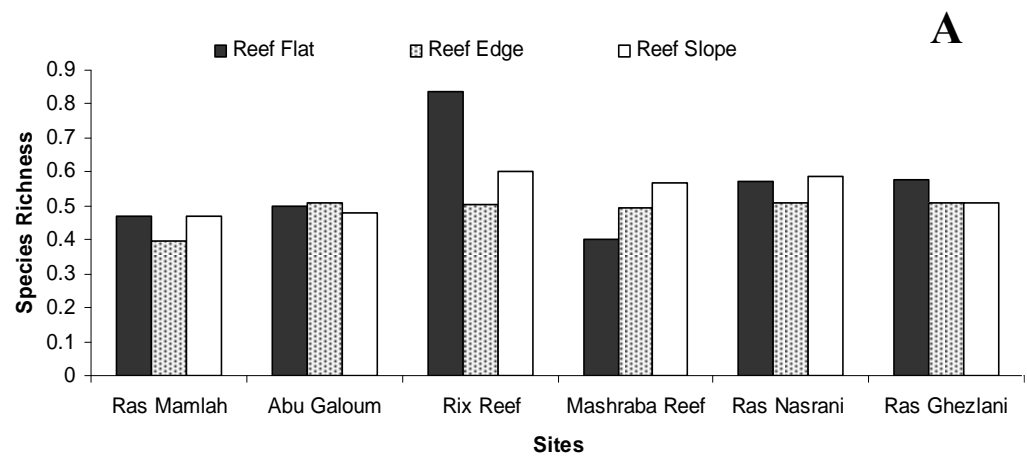



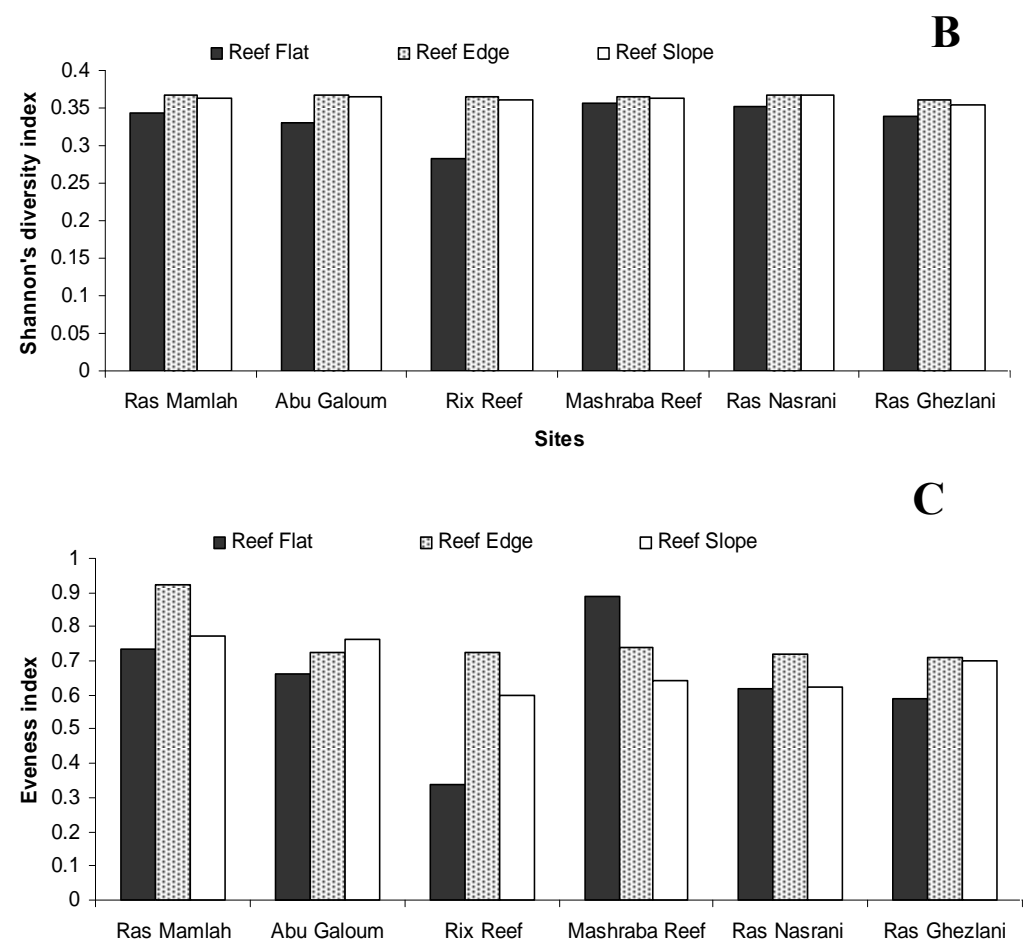

Figs. 4 A, B and C: Fish community parameters of diversity (species richness, Evenness and ShannonWiener) of goatfishes on the different reef zones.

\section{Size variation along zones:}

Individuals living in the reef slope had bigger sizes than those on the reef flat and edge (Fig. 5). However the variations in size between individuals was not significant $(P=0.182)$. Regardless to zones, the size of goatfish's species along the Gulf of Aqaba ranged between $14.8 \mathrm{~cm}$ to $24.3 \mathrm{~cm}$.

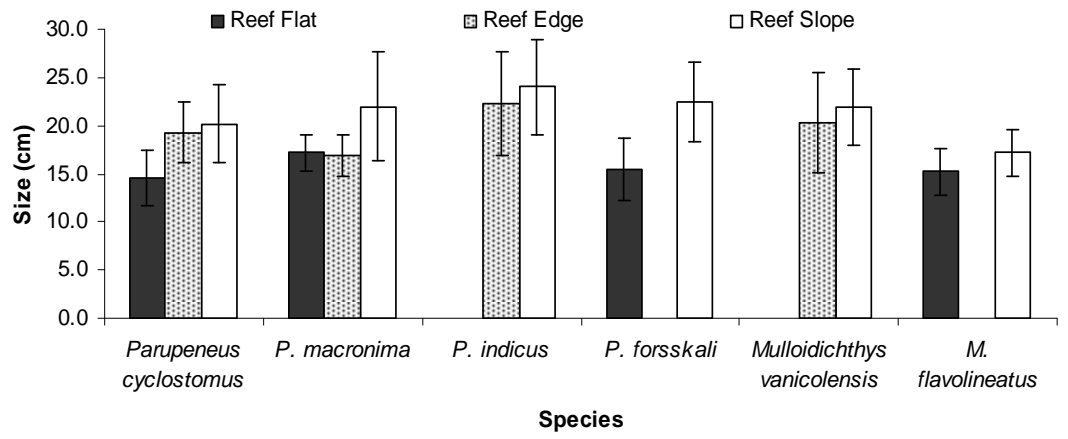

Fig. 5: Mean sizes $( \pm \mathrm{SD})$ of the recorded goatfishes on the three different zones; reef flat, reef edge, and reef slope.

\section{DISCUSSION}

The great variation of reef fishes populations are commonly influenced by many factors, such as reef types or environmental conditions (Wellington, 1992) and can also result from combinations of some unique biological or physical factors that could affect the diversity of the reef fishes (Alwany, 2008). Local populations of marine reef fishes often show great spatial variation in abundance (Holbrook et al., 
2000). This variation results from a combination of many physical and biological factors that affect fish distribution and diversity. The density and distribution of many species of coral reef fishes are strongly associated with habitat characteristics (Bell and Galzin, 1984; Chapman and Kramer, 1999).

In the present study, the total recorded number of species was six species of goatfishes along the Egyptian coast of Aqaba Gulf. This low species richness of this fishes along Gulf of Aqaba, was generally lower than that observed on coral reefs elsewhere throughout the Red Sea (Khalaf \& Disi, 1997; Golani, 1999; Al-Rousan et al., 2005) and other seas (Randall, 2004). The low diversity of mullids recorded in Aqaba Gulf may be attributed to recent historical origin of the Red Sea and Gulf of Aqaba.

\section{General distribution of goatfishes:}

Goatfishes showed constancy in species occurrence and distribution along the eastern coast of Sinai Peninsula. Gosline (1984) reported the possibility of the presence of more than one species of goatfish in the same location, and that goatfishes have evolved a unique ecological niche based on their hunting technique but not on their feeding items. The species distribution of goatfishes is not significantly correlated with the geographic distribution of the selected locations. However, that contrasts with the reports concludes that the coral reef may show a difference in communities' structure between northern and southern reefs of the Red Sea (Sheppard and Sheppard, 1991).

Our study showed a variation in the abundance of goatfish individuals and a significant correlation between the geographic distribution and the density of the goatfish. As we recorded that numbers of goatfishes increased in the southern regions than the northern regions, southern sites were located in Ras Mohammed National park, which considered a strict non-take zone, and that supported by some other studies on the same area conceding different families. Alwany \& Stachowitsch (2007) showed a significant increase of individuals in the southern regions than that of the northern ones. The non-fishing and disturbing activities in the southern regions are among the environmental factors that may affect the presence of the goatfishes in the study area. Also, there is concern that overfishing has drastically reduced populations of coral reef fishes in many locations (Jennings and Polunin, 1997; Friedlander and DeMartini, 2002; Bellwood et al., 2004; Dulvy et al., 2004).

The species richness of the 6 families (Pomacentridae, Chaetodontidae, Acanthuridae, Labridae, Scaridae and Serranidae) was examined in the different regions of the northern Red Sea, Gulf of Suez and Gulf of Aqaba by Sheppard et al. (1992) and Alwany \& Stachowitsch (2007). They noted a decreasing number of species, from southern coast of Egypt to northern Aqaba Gulf. Our results in agree with that were finding along the Gulf of Aqaba.

\section{Zonation of goatfishes}

The significant variation in the abundance of goatfish species in different zones in our study was supported by Golani (1994), who mentioned that species distribution is strongly dependent on the depth patterns. Moreover, Krajewski et al (2006) explained that a difference between the goatfish species in zones distribution is possibly to minimize potential resources overlap. Also, the more abundant native goatfishes the more appear to overlap one another only superficially in their use of space in the water column, and show different degrees of association with primary reef and the substrate (Schumacher and Parrish, 2005).

Most of goatfish are carnivorous; feed mainly on small crustaceans and invertebrates (Hiatt \& Strasburg, 1960) and they usually sheltered in seawards reefs 
(McCormick, 1995). So, our results showed that goatfishes are more abundant in the reef slope than the reef flat and that agreed by Alwany (2008); that carnivorous fishes usually tend to occur more at the reef slope than the reef flat and backreef. Also, our results showed that goatfishes tend to balance their habitat with their feeding requirements.

When focusing on the size difference, Lukoschek and McCormick (2001) reported that small fishes spent more time foraging on the reef flat and edge, compared with larger fishes that foraged on the reef slope, but this contrasted with our results that the body sizes are not significantly vary according to zones difference. This concludes that goatfishes in all sizes occur in all zones in the reef despite the topography (Munro, 1976) of the shelf, also the possibility that immature stages preference of the shallow water, supported by Munro (1976) in some goatfishes there is no indication that local or regional migration occurs from the point of settlement of the post larvae.

\section{CONCLUSION}

Goatfishes tend to balance their habitat presence with their survival requirements such as occurrence in less disturbance zones or association with certain substratum. Hence, goatfishes have evolved a unique ecological niche based on their hunting technique, and the differences between the goatfish species in zones distribution is possibly to minimize a potential resources overlap. Goatfishes also tend to balance their habitat with their feeding requirements. Goatfishes in all sizes occur in all reef zones. This new evidence of potentially detrimental interactions of introduced coral reef fishes on natives, underscores the need for further study of such behavioral and ecological relationships.

\section{REFERENCES}

Al-Rousan, S.A.; Rasheed M.Y.; Khalaf M.A. and Bardan M.I. (2005). Ecological and geochemical characteristics of bottom habitats at the northern Jordanian coast of the Gulf of Aqaba. Chem. Ecol., 21(4): 227-239.

Alwany, M. A. (1997). Ecological and biological studies on some coral reef fishes in south Sinai (Red Sea-Gulf of Aqaba). M. Sc. Thesis, Suez Canal University, Ismailia, Egypt, 283 pp.

Alwany, M. A. (2008). Species diversity and quantitative distribution of the surgeon fishes (Family: Acanthuridae) along Aqaba Gulf, Red Sea, Egypt. J. Aquat. Biol. \& Fish., 12: 93-107.

Alwany, M. A. and Stachowitsch M. (2007). Distribution and diversity of six common reef fish families along the Egyptian coast of the Red Sea. J. Aquat. Biol. Sci, 2 (1): 1-16.

Azzouz, K.; Diatta Y.; Mansour S.; Boumaiza M.; Ben Amor M.M. and Capapé C. (2011). First record of the west African goatfish, Pseudupeneus prayensis (Actinopterygii: Perciformes: Mullidae), off the Tunisian coast (central Mediterranean). Acta Ichthylogica Piscatoria, 41: 133-136,

Bariche, M.; Bilecenoglu M. and Azzurro E. (2013). Confirmed presence of the Red Sea goatfish Parupeneus forsskali (Fourmanoir \& Guézé, 1976) in the Mediterranean Sea. BioInvasions Records, 2: 173-175.

Bell, J. D. and Galzin R. (1984). Influence of live coral cover on coral reef fish communities. Mar. Ecol. Prog. Ser., 15: 265-274. 
Bellwood, D.R.; Hughes T.P.; Folke C. and Nystroem M. (2004) Confronting the coral reef crisis. Nature, 429: 827-833.

Bergman, K. C.; Öhman M.C. and Svensson S. (2000). Influence of habitat structure on Pomacentrus sulfurous, a western Indian Ocean reef fish. Environ. Biol. Fish., 59: 243-252.

Chapman, M.R. and Kramer, D.L. (1999). Movements of fishes within and among fringing coral reefs in Barbados. Environ. Biol. Fish., 57: 11-24.

Çinar, M.E.; Bilecenoglu M.; Ozturk B. and Can A. (2006). New records of alien species on the Levantine coast of Turkey. Aquatic Invasions, 1(2): 84-90.

Done, T. J. (1982). Patterns in the distribution of coral communities across the Great Barrier Reef. Coral Reefs 1: 95-107

Dor, M. and Ben-Tuvia, A. (1984). Mullidae In: M. Dor CLOFRFS, Checklist of the fishes of the Red Sea. Isl. Acad. Human Jerusalem: pp 161-164.

Dulvy, N. K.; Freckleton, R.P. and Polunin, N.V.C. (2004). Coral reef cascades and the indirect effects of predator removal by exploitation. Ecological Letter, 7: 410-416.

El-Drawany, M. A. (2013). Some biological aspects of the Por's goatfish, (Family: Mullidae) from Tripoli Cost of Libya. Egypt. J. Aquat. Rese., 39: 261-266.

Friedlander, A. M. and DeMartini, E. E. (2002). Contrasts in density, size, and biomass of reef fishes between the northwestern and the main Hawaiian Islands: the effects of fishing down apex predators. Mar. Ecol. Prog. Ser., 230: 253-264.

Garpe, K.C. and Öhman, M.C. (2003). Coral and fish distribution patterns in Mafia Island Marine Park, Tanzania: fish-habitat interactions. Hydrobiol., 498: 191211.

Glynn, P. W.; Veron, J.E.N. and Wellington, G.M. (1996). Clipperton Atoll (eastern Pacific): oceanography, geomorphology, reef-building coral ecology and biogeography. Coral Reefs, 15: 71-99

Golani, D. (1994). Niche separation between colonizing and indigenous goatfish (Mullidae) along Mediterranean coast of Israel. J. Fish Biol., 45: 503-513.

Golani, D. (1999). Fish colonization of an artificial reef in the Gulf of Elat, northern Red Sea. Environ. Biol. Fish., 54: 275-282.

Gosline, W. A. (1984). Structure, function and ecology in the goatfishes (family Mullidae). Pacific Sci., 38: 312-323.

Harmelin-Vivien, M. L. (1989). Implications of feeding specialization on recruitment processes and community structure of butterfly fishes. Environ. Biol. Fish., 25(1-3): 101-110.

Hiatt, R.W. and Strasburg, D.W. (1960). Ecological relationships of the fish fauna on coral reefs of the Marshall Islands. Ecolog. Monog., 30: 65-127.

Holbrook, S.J.; Forrester, G.E. and Schmitt, R.J. (2000). Spatial patterns in abundance of a damselfish reflect availability of suitable habitat. Oecologia, 122: 109-120.

Jennings, S. and Polunin, N.V.C (1997). Impacts of predator depletion by fishing on the biomass and diversity of non-target reef fish communities. Coral Reefs, 16: 71-82.

Khalaf, M.A. and Disi, A.M. (1997). Fishes of the Gulf of Aqaba. Marine Science Station, Aqaba, Jordan, $252 \mathrm{pp}$.

Kim, B.J. (2002). Comparative anatomy and phylogeny of the family Mullidae (Teleostei: Perciformes). Memoirs of the Graduate School of Fisheries Sciences Hokkaido University, 49: 1-7. 
Krajewski, J. P.; Bolando, R. M.; Sazima, C. and Sazima, I. (2006). Foraging activity and behaviour of two goatfish species (Perciforms: Mullidae) at Fernando de Moronha Archpelago, tropical west Atlanta. J. Environ. Biol. Fish., 77: 1-8.

Labropoulou, M. and Eleftheriou, A. (1997). The foraging ecology of two pairs of congeneric demersal fish species: importance of morphological characteristics in prey selection. J. Fish Biol., 50: 324-340.

Lukoschek, V. and McCormick, M. I. (2001). Ontogeny of diet changes in a tropical benthic carnivorous fish, Parupeneus barberinus (Mullidae): Relationship between foraging behaviour, habitat use, jaw size, and prey selection. Mari. Biology, 128: 1099-1113.

McClanahan, T. R. and Arthur, R. (2001). The effect of marine reserves and habitat on populations of East African coral reef fishes. Ecol. Appl., 11: 559-569

McCormick, M. I. (1995). Fish feeding on mobile benthic invertebrates: influence of variability in habitat associations. Mar. Biol., 121: 627-637.

Munro, J. L. (1976). Aspects of the biology and ecology of Caribbean reef fishes: Mullidae (goatfishes). J. Fish Biol., 9: 79-97.

Nelson, J. S. (2006). Fishes of the world. New Jersey: John Wiley \& Sons Inc, 601 $\mathrm{pp}$.

Pielou, E.C. (1966). Shannon's formula as a measure of specific diversity. Its use and misuse. American Naturalist., 100: 463-465

Platell, M. E. and Potter, I. C. (2001). Partitioning of food resources amongst 18 abundant benthic carnivorous fish species in marine waters on the lower west coast of Australia. J. Experiment. Mar. Biol. Ecol., 261: 31-54.

Platell, M. E.; Potter, I. C. and Clarke, K. R. (1998). Do the habitats, mouth morphology and diets of the mullids Upeneichthys stotti and U. lineatus in coastal waters of south-western Australia differ? J. Fish Biol., 52: 398-418.

Rajsuriya, A.; Öhman, M.C. and Johnstone, R.W. (1998). Coral and sandstone reefhabitats in southern Sri Lanka: patterns in the distribution of coral communities. Ambio., 27: 726-728.

Randall, J.E. (1983). Red Sea Reef Fishes. IMMEL publishing, London, UK, 192 pp

Randall, J.E. (2004). Revision of the goatfish genus Parupeneus (Perciformes: Mullidae), with descriptions of two new species. Indo-Pacific Fishes, 36: 1-64.

Schumacher, S. and Parrish, N. (2005). Spatial relationships between an introduced snapper and native goatfishes on Hawaiian reefs. Biological Invasions, 7: 925933.

Sheppard, C.R.C. and Sheppard A.L.S. (1991). Corals and coral communities of Arabia. Fauna Saudi Arabia 12: 3-170.

Sheppard, C.R., Price, A.R. and Roberts, C.M. (1992). Marine ecology of the Arabian region: Patterns and processes in extreme tropical environments, Academic Press, pp: 359.

Stergiou, K. I. and Karpouzi, V. S. (2001). Feeding habits and trophic levels of Mediterranean fish. Rev. Fish Biol. Fish., 11: 217-254.

Uiblein, F. and Heemstra, P.C. (2010). A taxonomic review of the Western Indian Ocean goat fish genus Upeneus (family: Mullidae), with description of four new species. Smithiana Bulletin, 11: 35-71.

Wellington, G.M. (1992). Habitat selection and juvenile persistence control the distribution of two closely related Caribbean damselfishes. Oecologia, 90: 500508. 


\section{ARABIC SUMMRY}

توزيع وتمنطق أسماكك البربونى (عائلة: ميوليدى) القاطنة فى شمال البحر الأحمر، جنوب سيناء، مصر

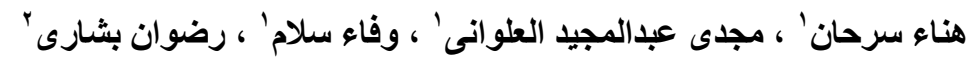

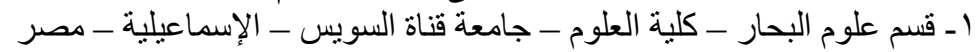

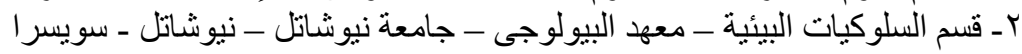

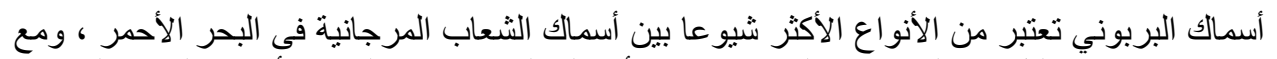

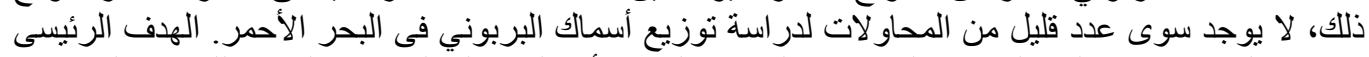

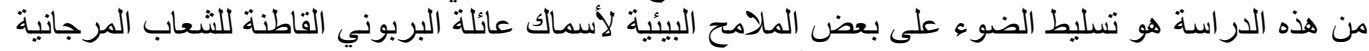

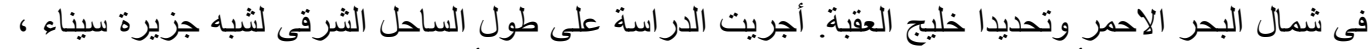

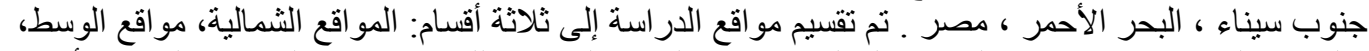

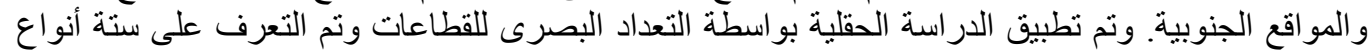

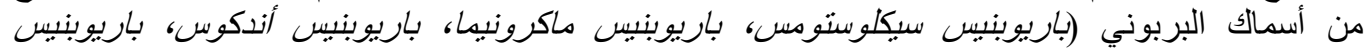

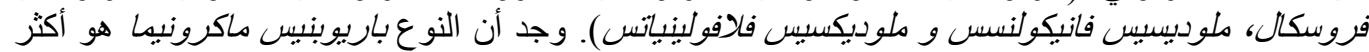

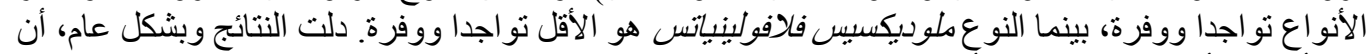

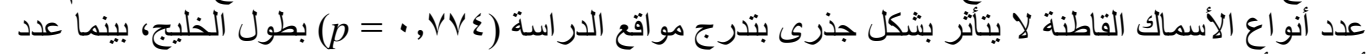

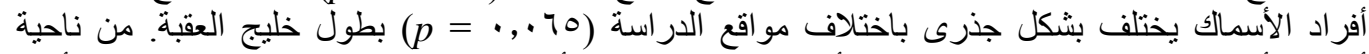

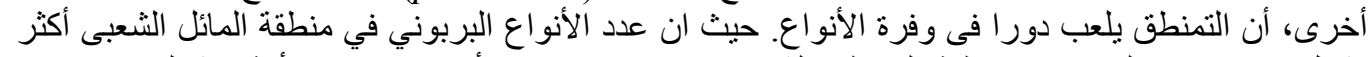

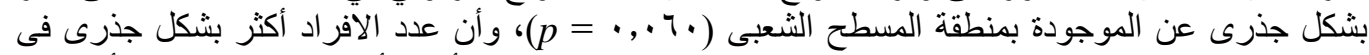

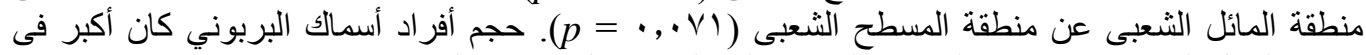

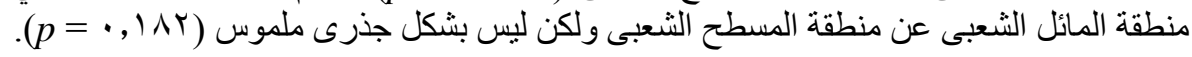

